\title{
Can VAT improve technical efficiency in China?-based on the SFA model test
}

\author{
YanFeng Jiang \\ Department of Public Economics, Xiamen University, Siming South Road in Xiamen City, People's \\ Republic of China, 086-361005 \\ Jiangyanfeng2011@126.com
}

Keywords: Value added tax Technical efficiency Production efficiency Scale efficiency

\begin{abstract}
This paper empirically tests how the change of value added tax impacts on technical efficiency based on the SFA model. The results show, if the proportion of the value added tax is higher, it is not good for the technical efficiency. We suggest, in the design of the VAT system, we should pay more attention to its influence on technical efficiency. For example, implement value added tax subsidy for technology research and development (R\&D).
\end{abstract}

\section{Introduction}

In the numerous factors influencing productivity, tax, as the most important part of the economic system, its influence can not be ignored. The reform of the tax system in 1994 established the basic framework of the current tax system. In the framework of the existing tax system, the effect of VAT on China's economy has been the major concern constantly. One important reason is that, value added tax is the major tax in china's tax system. Value added tax is based on the added value in production and circulation. The legal nominal tax rate is $17 \%$, and $13 \%$ is the low tax rate in China.

How this popular tax impacts China's technical efficiency is this paper's main concern, the lack of empirical econometric analysis is a weak point of former studies. We will from the provincial level specially probe into how the change of the proportion of the value added tax impacts on technical efficiency based on the SFA model.

\section{Literature Review}

Value added tax is only a tax on final consumption, so as long as the design is appropriate, VAT is a particularly efficient tax. Value added tax is in accordance with the neutral tax, can avoid the low efficiency of some other indirect tax.

But, Value added tax has some potential disadvantages and is not conducive to efficiency. When the transaction chain once broken, value added tax will lead to the loss of efficiency. In addition, because tax system is not perfect, and the statutory tax rebate is too high, these means the value added tax will not help the export and trade (Desai-Hines, 2005[1]).Meanwhile, Value added tax will have a negative impact on informal sector of the economy (Piggott and Whalley, 2001[2]; Emran and Stiglitz, 2005[3]; Keen, 2008[4]).

Therefore, based on the not clear performance of value added tax, whether value added tax is conducive to the improvement of the technical efficiency is only one empirical study (Keen and Lockwood, 2010)[5].

\section{The Model Specification}

The Decomposition of Total Factor Productivity. For a long time, the neoclassical economic growth theory saw the growth rate of total factor productivity as the technology progress. Many studies do not distinguish the total factor productivity, in fact, total factor productivity can be decomposed into technical progress, production efficiency, scale efficiency and resource production efficiency(Kumbhakar and Lovell, 2000)[6].

The Trans-Log Production Function. This paper adopts trans-log production function. This function has the following advantages: (1) Allow substitution elasticity variable among inputs factor. (2) Allow the existence of the non neutral technological advances, and technological progress can 
be decomposed into a common item and a particular item changing with different regions and time.(3) The TFP can be decomposed into technical progress item, production efficiency item and scale efficiency item conveniently. Taking into account the capital and labor as the main input factors of production and technical progress, we put the concrete form of the trans-log production function is:

$$
\begin{aligned}
\ln Y_{i t} & =\beta_{0}+\beta_{1} \ln K_{i t}+\beta_{2} \ln L_{i t}+\beta_{3} t+\beta_{4} \frac{\ln ^{2} K_{i t}}{2}+\beta_{5} \frac{\ln ^{2} L_{i t}}{2} \\
& +\beta_{6} \frac{t^{2}}{2}+\beta_{7} \ln K_{i t} \ln L_{i t}+\beta_{8} t \ln K_{i t}+\beta_{9} t \ln L_{i t}+\varepsilon_{i t}
\end{aligned}
$$

Here, $Y_{i t}, K_{i t}, L_{i t}$ represents real output, real capital and labor for province $i$ in time $t$ respectively. $t$ is the time trend, denotes technology progress.

Based on the type of trans-log production function, then we can define capital output elasticity, labor output elasticity, scale elasticity for province $i$ in time $t$. In addition, we can also define technology progress rate as follows:

$$
\begin{aligned}
& E_{K i t}=\frac{\partial \ln Y_{i t}}{\partial \ln K_{i t}}=\beta_{1}+\beta_{4} \ln K_{i t}+\beta_{7} \ln L_{i t}+\beta_{8} t \\
& E_{L i t}=\frac{\partial \ln Y_{i t}}{\partial \ln L_{i t}}=\beta_{2}+\beta_{5} \ln L_{i t}+\beta_{7} \ln K_{i t}+\beta_{9} t \\
& E_{i t}=E_{K i t}+E_{L i t} \\
& T P_{i t}=\frac{\partial \ln Y_{i t}}{\partial \ln t}=\beta_{3}+\beta_{6} \ln t+\beta_{8} \ln K_{i t}+\beta_{9} \ln L_{i t}
\end{aligned}
$$

In the expressions above, $E_{K i t}, E_{L i t}, E_{i t}$ and $T P_{i t}$ denotes capital output elasticity, labor output elasticity, scale elasticity and technology progress rate respectively for province $i$ in time $t$.

The Stochastic Frontier Analysis. This paper adopts the stochastic frontier analysis(SFA) developed by Battese and Coelli[7], The basic idea for SFA is assuming the input factor $X_{i t}$ can produce $Y_{i t}$ in the most effective cases, SFA can be expressed as follows:

$$
Y_{i t}=X_{i t} \beta+\omega_{i t}-v_{i t} \quad i=1,2, \cdots, N ; t=1,2, \cdots T
$$

Here, $\beta$ is the parameter to be estimated, $Y_{i t}$ is the actual output, correspondingly in this paper, is the logarithm of real output for province $i$ in time $t ; X_{i t}$ is the input factor, it refers to the actual capital stock, labor force, time trend and the logarithm of its quadratic term and cross term correspondingly. $\omega_{i t}$ is the random error term, follows a standardized normal distribution $N\left(0, \sigma_{w}^{2}\right)$, independent to $v_{i t} ; v_{i t}$, the inefficiency item for province $i$ in time $t$, and the distribution of $v_{i t}$ could have four kinds in different situations: half normal distribution, truncated normal distribution, exponential distribution and gamma distribution. In this paper, we assume $v_{i t}$ obeys the half normal distribution $N\left(\mu_{i t}, \sigma_{v}^{2}\right)$, and is a nonnegative random variable. According to Battese and Coelli [7], $v_{i t}$ can be expressed further as:

$$
v_{i t}=Z_{i t} \gamma+\varepsilon_{i t}
$$

Here, $\gamma$ is the parameter to be estimated, $Z_{i t}$ is each factor that affects the inefficiency item, independent of the production process. This paper introduces the following variables as the factors 
that affect the inefficiency item: The proportion of State owned industrial output accounted for the total industrial output, the proportion of fiscal expenditure accounted for GDP, the proportion of exports accounted for GDP, the initial human capital, the initial physical capital, the ratio of value added tax accounted for tax revenue, the regional dummy variables; $\varepsilon_{i t}$ obeys the normal distribution $N\left(0, \sigma_{\varepsilon}^{2}\right)$. The technical efficiency term can be defined as:

$$
T E_{i t}=\exp \left\{-v_{i t}\right\}=\exp \left\{-Z_{i t} \gamma-\varepsilon_{i t}\right\}
$$

Estimation Method. For the estimation of production function and the inefficiency production function, early researchers used two step estimation method. Firstly estimate the production function, and then calculate the inefficiency term. Finally estimate the production inefficiency equation. Because SFA contains a composite error, the least square method is no longer applicable. (Battese and Coelli, 1995, [7]) recommended the use of maximum likelihood estimation. There are some defects in the measurement as to the two step estimation method, so later one step estimation method was developed to compensate for the method of two step estimation. In order to compare the robustness of models, two methods are both used in this paper.

\section{Data Specification}

We used the data mainly from China's statistical yearbook, provincial statistical yearbook, "Compilation of statistical data in recent sixty years of China", the network database etc. We adopted the panel data of provinces. The initial time is 1994 in which year the reform of localized fiscal tax system was started, and the ending year is 2011.

The statistical characteristics of variables are shown in Table 1:

Table 1: Variables and statistical characteristics

\begin{tabular}{l|c|c|c|c|c}
\hline \multicolumn{1}{c|}{ Variables } & Obs. & Mea. & Sta. & Min & Max \\
\hline $\begin{array}{l}\text { Real GDP [Billion RMB] } \\
\text { The actual capital }\end{array}$ & 504 & 691.2 & 575.7 & 35.83 & 3385 \\
[Billion RMB] & 504 & 3862 & 4625 & 120.1 & 35000 \\
Labor force [Million] & 504 & 2474 & 1664 & 232.7 & 6486 \\
The proportion of VAT & 504 & 0.216 & 0.0510 & 0.0830 & 0.396 \\
Marketization & 504 & 0.525 & 0.208 & 0.107 & 0.899 \\
Government intervention & 504 & 0.150 & 0.0720 & 0.0490 & 0.579 \\
Open degree & 504 & 0.164 & 0.195 & 0.0150 & 0.937 \\
The initial human capital & 504 & 0.605 & 0.0960 & 0.427 & 0.778 \\
The initial capital & & & & & \\
[Billion RMB] & 504 & 146.7 & 74.98 & 37.44 & 370.6 \\
\hline
\end{tabular}

The main variables and interpretations:

The real GDP $\left(Y_{i t}\right)$. We computed the GDP based on the year 1978 according to the index of GDP and the nominal GDP. The actual capital $\left(K_{i t}\right)$.We calculated the actual capital stock according to the perpetual inventory method. We suppose the depreciation rate is $10 \%$, and the actual capital stock in 1978 see as the base period. The labor $\left(L_{i t}\right)$ is the number of employees. The proportion of the value added tax $\left(V A T_{i t}\right)$. We measure the index by the ratio of domestic value added tax accounted for tax revenues in each province. The efficiency index. We decompose total factor productivity into technology progress efficiency $\left(T P_{i t}\right)$, production efficiency $\left(T E_{i t}\right)$, and scale efficiency $\left(S E_{i t}\right)$. Technology progress efficiency $\left(T P_{i t}\right)$ is calculated by the formula applied by (Kumbhakar and Lovell, 2000) [6]. The control variables. The control variables we select including: the level of the market ( market $_{i t}$ ), which is denoted by the proportion of the total state owned industrial accounted for total industrial. The degree of government intervention ( government $_{i t}$ ) is measured by the proportion of fiscal expenditure accounted for GDP. The degree 
of openness is viewed by the proportion of exports accounted for GDP. The initial stage of the human capital stock $\left(h c_{i t}\right)$ is measured by the population ratio that the persons educated exceed primary school in 1982. Physical capital stock $\left(m c_{i t}\right)$ is measured by the actual capital stock in 1978.

\section{Empirical Test for the Effect of Value Added Tax on Technical Efficiency}

Production function and the production inefficiency equation as follows

$$
\begin{aligned}
\ln Y_{i t}= & \beta_{0}+\beta_{1} \ln K_{i t}+\beta_{2} \ln L_{i t}+\beta_{3} t+\beta_{4} \frac{\ln ^{2} K_{i t}}{2}+\beta_{5} \frac{\ln ^{2} L_{i t}}{2} \\
& +\beta_{6} \frac{t^{2}}{2}+\beta_{7} \ln K_{i t} \ln L_{i t}+\beta_{8} t \ln K_{i t}+\beta_{9} t \ln L_{i t}+\omega_{i t}-v_{i t} \\
v_{i t}=\gamma_{0} & +\gamma_{1} \ln v_{a t}+\gamma_{2} \text { market }_{i t}+\gamma_{3} \text { government }_{i t}+\gamma_{4} \text { openness }_{i t}+\gamma_{5} h c_{i t}+\gamma_{6} m c+\gamma_{7} \text { east }_{i t}+\gamma_{8} \text { west }_{i t}+\varepsilon_{i t}
\end{aligned}
$$

The technical efficiency equation is:

$$
\mathrm{TP}_{i t}=\alpha_{0}+\alpha_{1} \ln v a t_{i t}+\alpha_{2} \text { market }_{i t}+\alpha_{3} \text { government }_{i t}+\alpha_{4} \text { openness }_{i t}+\alpha_{5} h_{i t}+\alpha_{6} m c+\alpha_{7} \text { east }{ }_{i t}+\alpha_{8} \text { west }_{i t}+u_{i t}+\xi_{i t}
$$

The scale efficiency equation is:

$$
S E_{i t}=\alpha_{0}+\alpha_{1}{\ln v a t_{i t}}_{i t}+\alpha_{2} \text { market }_{i t}+\alpha_{3} \text { government }_{i t}+\alpha_{4} \text { openness }_{i t}+\alpha_{5} h c_{i t}+\alpha_{6} m c+\alpha_{7} \text { east }_{i t}+\alpha_{8} \text { west }_{i t}+w_{i t}+\xi_{i t}
$$

The estimation results are showed in Table 2.

The Analysis of Trans-Log Production Function Estimation. The estimation results are with little difference, this proves the estimation results of the trans-log production function based on SFA model is relatively robust. At the same time, most variables and their quadratic items in the production function are very significant.

The Analysis of the Production (in) Efficiency Equation Estimation. Similarly, following the two methods, we obtain the estimation value of production efficiency. We mainly focus on the effect of the proportion of the value added tax on production efficiency. From Table 2, we can conclude: The proportion of the value added tax has a positive impact on production efficiency, and the positive effect is remarkable whether under one step method or two step method. The larger the proportion of value added tax in the tax structure, the higher production efficiency.

The Analysis of Technical Efficiency Equation Estimation. The Hausman test suggests that we should use the fixed effect model to estimate technical efficiency equation, therefore, we omit the regional dummy variables and the initial capital stock. From the estimation results, the larger the proportion of the value added tax, the less conducive to the technological progress, and the conclusion not only significant but robust. Relatively speaking, technology research and development should face the risk of research activity, but there is not enough subsidy for R\&D to compensate for this risk in the value added tax system. Therefore, the value-added tax does not have comparative advantages over other taxes on promoting technological progress.

The Analysis of Scale Efficiency Equation Estimation. The Hausman test suggested a random effects model in the estimation of scale efficiency equation. Therefore, we use the generalized least square method to estimate the model. We found that, the larger of the value added tax, the less conducive to the scale efficiency, and the effect is significant and robust. 
Table 2: Estimation of the production function and efficiency equation

\begin{tabular}{|c|c|c|c|c|c|c|c|c|}
\hline & \multicolumn{2}{|c|}{$\begin{array}{l}\text { The trans-log production } \\
\text { function estimation }\end{array}$} & \multicolumn{2}{|c|}{$\begin{array}{l}\text { The production (in) } \\
\text { efficiency equation } \\
\text { estimation }\end{array}$} & \multicolumn{2}{|c|}{$\begin{array}{l}\text { Technical efficiency } \\
\text { equation estimation }\end{array}$} & \multicolumn{2}{|c|}{$\begin{array}{c}\text { Scale efficiency } \\
\text { equation estimation }\end{array}$} \\
\hline & $\begin{array}{l}\text { Two step } \\
\text { method }\end{array}$ & $\begin{array}{l}\text { one step } \\
\text { method }\end{array}$ & $\begin{array}{l}\text { Two step } \\
\text { method }\end{array}$ & $\begin{array}{l}\text { one step } \\
\text { method }\end{array}$ & $\begin{array}{l}\text { Two step } \\
\text { method }\end{array}$ & $\begin{array}{l}\text { one step } \\
\text { method }\end{array}$ & $\begin{array}{l}\text { Two step } \\
\text { method }\end{array}$ & $\begin{array}{l}\text { one step } \\
\text { method }\end{array}$ \\
\hline $\ln K$ & $\begin{array}{l}2.973^{* * *} \\
(0.310)\end{array}$ & $\begin{array}{c}2.430 * * * \\
(-0.453) \\
\end{array}$ & & & & & & \\
\hline $\ln L$ & $\begin{array}{l}-1.854^{* * *} \\
(0.269)\end{array}$ & $\begin{array}{l}-1.294^{* * *} \\
(0.419)\end{array}$ & & & & & & \\
\hline $\mathrm{t}$ & $\begin{array}{l}-0.384^{* * *} \\
(0.467)\end{array}$ & $\begin{array}{l}-0.342^{* * *} \\
(-0.068)\end{array}$ & & & & & & \\
\hline$(\ln K)^{2}$ & $\begin{array}{l}-0.285^{* * *} \\
(-0.069)\end{array}$ & $\begin{array}{l}-0.172^{*} \\
(-0.088)\end{array}$ & & & & & & \\
\hline$(\operatorname{lnL})^{2}$ & $\begin{array}{l}0.383^{* * *} \\
(0.047)\end{array}$ & $\begin{array}{l}0.351^{* * *} \\
(-0.066)\end{array}$ & & & & & & \\
\hline $\mathrm{t}^{2}$ & $\begin{array}{c}0.001 \\
(0.002)\end{array}$ & $\begin{array}{c}0.003 \\
(0.003) \\
\end{array}$ & & & & & & \\
\hline $\ln K \ln L$ & $\begin{array}{l}-0.092^{* *} \\
(0.038) \\
\end{array}$ & $\begin{array}{l}-0.134^{* * *} \\
(0.041)\end{array}$ & & & & & & \\
\hline $\operatorname{tlnK}$ & $\begin{array}{l}0.040^{* * *} \\
(0.010)\end{array}$ & $\begin{array}{l}0.028^{* *} \\
(0.013)\end{array}$ & & & & & & \\
\hline $\operatorname{tln} \mathrm{L}$ & $\begin{array}{l}0.012^{*} \\
(0.006)\end{array}$ & $\begin{array}{l}0.017^{* * *} \\
(0.006)\end{array}$ & & & & & & \\
\hline lnvat & & & $\begin{array}{l}0.001^{* * *} \\
(0.000)\end{array}$ & $\begin{array}{l}-3.200^{* *} \\
(1.451)\end{array}$ & $\begin{array}{l}-0.033^{* * *} \\
(0.005)\end{array}$ & $\begin{array}{l}-0.033^{* * *} \\
(0.005)\end{array}$ & $\begin{array}{l}-0.015^{* * *} \\
(0.003)\end{array}$ & $\begin{array}{l}-0.011^{* * *} \\
(0.003)\end{array}$ \\
\hline market & & & $\begin{array}{l}0.002^{* * *} \\
(0.000)\end{array}$ & $\begin{array}{l}-1.891 \\
(1.983) \\
\end{array}$ & $\begin{array}{l}-0.149^{* * *} \\
(0.010)\end{array}$ & $\begin{array}{l}-0.146^{* * *} \\
(0.010)\end{array}$ & $\begin{array}{l}0.025^{* * *} \\
(0.006)\end{array}$ & $\begin{array}{l}0.022^{* * *} \\
(0.005)\end{array}$ \\
\hline government & & & $\begin{array}{l}0.005^{* * *} \\
(0.001)\end{array}$ & $\begin{array}{l}-7.293 \\
(6.085) \\
\end{array}$ & $\begin{array}{l}0.366^{* * *} \\
(0.214)\end{array}$ & $\begin{array}{l}0.392^{* * *} \\
(0.022)\end{array}$ & $\begin{array}{l}0.062^{* * *} \\
(0.014)\end{array}$ & $\begin{array}{l}0.050^{* * *} \\
(0.011)\end{array}$ \\
\hline openness & & & $\begin{array}{l}0.001^{* *} \\
(0.000)\end{array}$ & $\begin{array}{l}-3.053 \\
(3.671)\end{array}$ & $\begin{array}{l}0.035^{* * *} \\
(0.012)\end{array}$ & $\begin{array}{c}0.041^{* * *} \\
(0.012)\end{array}$ & $\begin{array}{c}0.011 \\
(0.008)\end{array}$ & $\begin{array}{c}0.005 \\
(0.006)\end{array}$ \\
\hline hc & & & $\begin{array}{l}0.005^{* * *} \\
(0.001)\end{array}$ & $\begin{array}{c}-13.229^{* * *} \\
(3.641)\end{array}$ & $\begin{array}{l}-0.041 \\
(0.026)\end{array}$ & $\begin{array}{l}-0.051^{*} \\
(0.026)\end{array}$ & $\begin{array}{l}-0.094^{* * *} \\
(0.016)\end{array}$ & $\begin{array}{c}-0.078^{* * *} \\
(0.013)\end{array}$ \\
\hline $\mathrm{mc}$ & & & $\begin{array}{l}0.000^{* * *} \\
(0.000)\end{array}$ & $\begin{array}{l}-0.005 \\
(0.005)\end{array}$ & & & $\begin{array}{l}0.000^{* *} \\
(0.000)\end{array}$ & $\begin{array}{l}0.000^{* * *} \\
(0.000)\end{array}$ \\
\hline east & & & $\begin{array}{c}0.000 \\
(0.000)\end{array}$ & $\begin{array}{l}-1.149 \\
(1.366)\end{array}$ & & & $\begin{array}{l}-0.031^{* * *} \\
(0.012)\end{array}$ & $\begin{array}{l}-0.021^{* *} \\
(0.009)\end{array}$ \\
\hline west & & & $\begin{array}{c}-0.001^{* * *} \\
(0.000)\end{array}$ & $\begin{array}{c}0.853 \\
(0.716) \\
\end{array}$ & & & $\begin{array}{l}-0.008 \\
(0.012) \\
\end{array}$ & $\begin{array}{l}-0.007 \\
(0.009) \\
\end{array}$ \\
\hline $\begin{array}{l}\text { maximum like } \\
\text { lihood }\end{array}$ & -105.768 & -81.388 & -105.768 & -81.388 & & & & \\
\hline Panel model & & & & & $\mathrm{F}$ & $\mathrm{F}$ & $\mathrm{R}$ & $\mathrm{R}$ \\
\hline
\end{tabular}

Note: ${ }^{* * * * * *}$ represents the confidence level at $10 \%, 5 \%$ and $1 \%$ respectively 


\section{Summary}

Value added tax is an important part of the tax structure in China, and it has an important impact on technical efficiency. Technical efficiency is usually measured by total factor productivity, in fact, technical efficiency is only a part of TFP. How value added tax will affect technical efficiency, this problem might rely heavily on empirical analysis. Based on trans-log production function and stochastic frontier analysis, this paper carried the relatively comprehensive empirical test to analyse how the proportion of value-added tax in the tax structure impact on technical efficiency.

Our empirical results show that: The proportion of the value added tax has a significant negative impact on technical efficiency on average, that is to say, the larger the proportion of the value added tax, the less conducive to the technological progress. This may be because that technology R\&D faces the research risks, but the value added tax dose not render enough tax concessions for technology R\&D, and can not compensate for the technology R\&D risks, therefore, the value added tax does not have an advantage over other taxes on the promotion of technological progress.

In recent years, the China's government has carried out a series of adjustments for the value added tax system, including the transformation and expansion of value added tax, etc. These reforms really help to reduce the tax burden, but how value added tax affect technical efficiency should not be ignored. We suggest, with the reform "business tax change into valve added tax" and the expansion of the value added tax, we should focus on the design that can optimize the tax system. Technical efficiency is the core of economic growth, the value added tax system should not hinder the technology progress, and should give impetus to economic growth. For example, it is appropriate to supply tax subsidy for enterprises' technology R\&D, to avoid the enterprise employ capital to replace technology $R \& D$, and to encourage enterprises to increase $R \& D$ investment.

\section{References}

[1] Desai, Mihir A., Hines, James R. Jr., Value added taxes and international trade: the evidence. mimeo: University of Michigan, 2005.

[2] Piggott, John, Whalley, John, VAT base broadening, self supply, and the informal sector. American Economic Review 91, 2001, pp.1084-1094.

[3] Emran, Shahe M., Stiglitz, Joseph E., On selective indirect tax reform in developing countries. Journal of Public Economics 89, 2005, pp.599-623.

[4] Keen, Michael, VAT, tariffs, and withholding: Border taxes and informality in developing countries. Journal of Public Economics 92 (2), 2008, pp.1892-1906.

[5] Keen, Michael, Lockwood, Ben, The value added tax: Its causes and consequences. Journal of Development Economics 92, 2010, pp.138-151.

[6] S. C. Kumbhakar, C. A . K. Lovell, Stochastic Frontier Analysis. Cambridge University Press, 2000.

[7] Battese, G., Coelli,T., A model for technical inefficiency effects in a stochastic frontier production function. Empirical Economics 20, 1995, PP.325-332. 